\title{
PROPOSED MODEL ON LEVELS OF DEGRADED LAND AT MERAWU WATERSHED, BANJARNEGARA REGENCY, CENTRAL JAVA PROVINCE, INDONESIA
}

\author{
BAMBANG SULISTYO ${ }^{1 *}$, TOTOK GUNAWAN ${ }^{2}$, HARTONO², PROJO DANOEDORO \\ and ROCHMAT MARTANTO ${ }^{3}$ \\ ${ }^{1}$ Faculty of Agriculture, Universitas Bengkulu, Bengkulu 38371, Indonesia \\ ${ }^{2}$ Faculty of Geography, Universitas Gadjah Mada, Sleman, Yogyakarta 55281, Indonesia \\ ${ }^{3}$ National Land College, Sleman, Yogyakarta 55293, Indonesia
}

Received 30 November 2016/Accepted 10 June 2017

\begin{abstract}
Conservation of degraded land in Indonesia requires maps of degraded land. The maps were established based on a model developed in 1998 by the then Indonesia Department of Forestry. The model has 2 weaknesses i.e. 1. high level of uncertainty due to vector-based data used to build the thematic maps and 2. parameters redundancy or duplication from the model. This research was aimed to build up a proposed model on levels of degraded land at Merawu Watershed using fully raster-based data supported with remote sensing and GIS techniques. Parameters analyzed were Slope, Erosivity (R), Erodibility (K), Slope Length and Steepness (LS), Cover and Management (C), Support Practice (P) and Percentage of Canopy Cover. These data were presented in fully raster format. Management parameter was not explicitly used in this research because management parameter was already represented by the $\mathrm{C}$ and P parameters. Five parameters were directly obtained using fully raster format, i.e. Slope, LS, C, P and Percentage of Canopy Cover. The other 2 parameters went through spatial interpolation process before being presented as fully raster format. Correlation analysis among parameters was carried out. Parameters having high correlation coefficient $(\mathrm{r} \geq 0.8)$ were excluded from the model to avoid redundancy. The proposed model only used parameters having low correlation coefficient. The research result showed that the determination of levels of degraded land was more accurate when using only erosion parameters, formulated as:
\end{abstract}

Level of Degraded Land (LoDL) $\approx$ Erosion $\approx \mathrm{R} \times \mathrm{K} \times \mathrm{LS} \times \mathrm{C} \times \mathrm{P}$.

Keywords: Degraded land, GIS, raster, remodel, remote sensing

\section{INTRODUCTION}

Soil erosion management is a dilemmatic problem for developing countries such as Indonesia. Erosion is accelerating from year to year due to the uncontrollable pressure of population and economic growth (Fulazzaky \& Gany 2009; Sulistyo et al. 2009; Bohre \& Chaubey 2014; Sulistyo 2015a). There are six types of land degradation i.e. water erosion, wind erosion, soil fertility decline, salinitation, water logging and the lowering of water table (FAO 1994). In most of tropical countries such as Indonesia, degraded land is mostly caused by water erosion resulted from high intensity of rainfall (Abdurachman \&

*Corresponding author: bambangsulistyounib@gmail. com; bsulistyo@unib.ac.id
Sutono 2002), especially when land covers were removed. Soil of the bare land would be washed away by the runoff water to the lowest places or estuaries (Arsyad 2000).

Identification of degraded land can be done by investigating the condition of watershed areas. In Indonesia, the numbers of critical and highly eroded watershed areas are increasing from year to year (Hidayat et al. 2014; Kartodihardjo 2008).

To conserve the degraded land, it is important to identify the objectives of the conservation and to disseminate these objectives to the stakeholders in the form of maps of degraded land (Tarigan 2012; Gibbs \& Salmon 2015). These maps are usually developed from a model consisted of several chosen parameters, to reduce cost (Sulistyo et al.2017). 
In Indonesia, the model and guidelines are published through Decree No. 041/Kpts/V/ 1998 of 21 April 1998 by the Directorate General of Reforestation and Land Rehabilitation, Department of Forestry (Departemen Kehutanan 1998). This decree is updated through the Regulation of the Director General of Land Rehabilitation and Social Forestry on Guidelines for Monitoring and Evaluation of Watersheds, Number: P.04/V-Set/2009, dated 5 March 2009, but still using the same concept (Kementerian Kehutanan 2009). The model is implemented nationwide. Mathematically, the level of degraded land (abbreviated as LoDL for further discussion) is formulated as:

LoDL $=\mathrm{w}_{1}$ Slope $+\mathrm{w}_{2}$ Erosion $+\mathrm{w}_{3}$ Percentage of Canopy Cover $+\mathrm{w}_{4}$ Management .. (1)

where $\mathrm{w}_{1}, \mathrm{w}_{2}, \mathrm{w}_{3}$ and $\mathrm{w}_{4}$ are weighting factors.

The weighting factors are determined based on the criteria of the LoDL that are published and presented in tables.

Determination of the LoDL is initiated by computing the estimated erosion using USLE (Universal Soil Loss Equation) model developed by Wischmeier and Smith (1978), and formulated as:

$\mathrm{A}=\mathrm{R} \times \mathrm{K} \times \mathrm{LS} \times \mathrm{C} \times \mathrm{P}$

where:

$$
\begin{aligned}
& \mathrm{A}= \begin{array}{l}
\text { mean annual soil erosion rate in } \\
\text { (ton } / \text { hectare } / \text { year) }
\end{array} \\
& \mathrm{R}= \text { rainfall erosivity factor }(\mathrm{R} \text { factor) in }(\mathrm{MJ} \\
&\mathrm{mm} / \mathrm{ha} / \mathrm{h} / \mathrm{year}) \\
& \mathrm{K}= \begin{array}{l}
\text { soil erodibility factor }(\mathrm{K} \text { factor) in (ton } \\
\text { hectare } / \mathrm{MJ} / \mathrm{mm})
\end{array} \\
& \mathrm{LS}= \begin{array}{l}
\text { slope length and steepness factor }(\mathrm{LS} \\
\text { factor) }(\text { dimensionless) }
\end{array} \\
& \mathrm{C}= \begin{array}{l}
\text { cover and management factor }(\mathrm{C} \text { factor) } \\
\text { (dimensionless) }
\end{array} \\
& \mathrm{P}=\begin{array}{l}
\text { support practice factor }(\mathrm{P} \text { factor }) \\
\text { (dimensionless) }
\end{array}
\end{aligned}
$$

By replacing Erosion in equation (1) with equation (2), a new equation (3) becomes:

$\mathrm{LoDL}=\mathrm{w}_{1}$ Slope $+\mathrm{w}_{2}(\mathrm{R} \times \mathrm{K} \times \mathrm{LS} \times \mathrm{C} \times \mathrm{P})+\mathrm{w}_{3}$ Percentage of Canopy Cover $+\mathrm{w}_{4}$ Management.

Some weaknesses in the model are: 1) the input data are mostly simplified vector-based thematic maps leading to high uncertainty; and 2) the existing formula or model contains redundant or duplicate parameters. DeMers (2008) stated that the presentation of earth information in vector data model assumes the existence of homogeneity in a mapping unit as a result of classification and simplification, so that the variation of earth information is reduced, leading to uncertainties.

Those uncertainties can be minimized by applying a fully-raster-based model which is able to keep the variation and objectivity of earth information (Aronoff 1989; Hadmoko 2007). The fully-raster-based model is among technological advances in Remote Sensing (RS) and Geographical Information System (GIS) fields.

Sulistyo (2015a) studied land unit elimination analysis to determine LoDL using vector-based format. Land unit elimination causes a decrease in erosion rate, affects LoDL and finally influences the recommendations for conserving degraded land.

Originally, USLE is developed in small agricultural areas in North America having characteristics of moderate climate (low in rain intensity), slope $3-18 \%$, with consistent cropping and management system (Asdak 2007). Several modifications are needed when implementing USLE in locations having different characteristics, especially modifications on parameters used to provide more reliable erosion estimation.

Fistikoglu and Harmancioglu (2002) concluded that erosion model developed using USLE was more reliable when the analysis was carried out using small raster-based data. Sulistyo et al. (2009) proved that erosion modeling using fully-raster-based data provided very high accuracy compared to the actual erosion. A fullyraster-based erosion model uses raster-formatted data input. The raster-formatted data input are not products of Vector to Raster Conversion algorithm.

Three USLE parameters (LS, C and P) can directly produce raster-formatted data, while data provided by the other two USLE parameters ( $\mathrm{R}$ and $\mathrm{K}$ ) has to be transformed using spatial interpolation to obtain raster-formatted data. Spatial interpolation is the process of using points with known values, to estimate the values of the other points (Chang 2008).

Several parameters of USLE were analyzed respectively i.e. R, C, LS, and K (Sulistyo 2011a; Sulistyo 2011b; Sulistyo et al. 2011; Sulistyo 
2015b). Percentage of Canopy Cover was also analyzed (Sulistyo et al. 2013). All those parameters were analyzed using raster-based data format.

This study was aimed to develop alternative model for LoDL at Merawu Watershed, using raster-based data format to avoid parameters redundancy or duplication.

\section{MATERIALS AND METHODS}

This research is the ultimate research on degraded land by the first author. Several preliminary studies on this subject were already published by the first author, i.e. Sulistyo et al. 2009; Sulistyo 2011a; Sulistyo 2011b; Sulistyo et al. 2011; Sulistyo et al. 2013; Sulistyo 2015b; Sulistyo 2016 and Sulistyo et al. 2017. Therefore, the data, hardware, software, research areas and methods used in this research were similar to those preliminary studies.

\section{Study Area}

The study area was located at Merawu Watershed, geographically lied at 10941'24" 10950'24" E and 710'12" - 722'12" S, administratively located in Banjarnegara District, Central Java Province, Indonesia. Merawu Watershed covered an area of $\pm 22,734$ ha with 3 main rivers flowing through the area from north to south i.e. Merawu, Urang and Penaraban Rivers (Fig. 1).

\section{Data and Methods}

Data used were topographical map, landform map, remotely-sensed data of Landsat $7 \mathrm{ETM}^{+}$, rainfall data recorded at Merawu Watershed and its surroundings, as well as other data and reports related to the study. GIS software used were ILWIS (Integrated Land and WaterInformation System) version 3.4 and ArcView version 3.3. Several equipment used for field work were binoculars, compass, Hagameter, Munsell soil color chart, tape, soil sample ring kit, Auger soil boring tool, Global Positioning System tool and digital camera.

Data from all parameters affecting LoDL were analyzed as fully-raster-based format. Pixel size used for this study was $30 \times 30 \mathrm{~m}$. LoDL model was developed using fully-raster-based data format (Fig. 2).

The main research stages were creating all LoDL parameters, then implementing correlation analysis among parameters. To implement correlation analysis among parameters, all data had to be presented in quantitative form. To fulfil this requirement, the Management factor as qualitative factor had to be excluded from equation (3). Moreover,

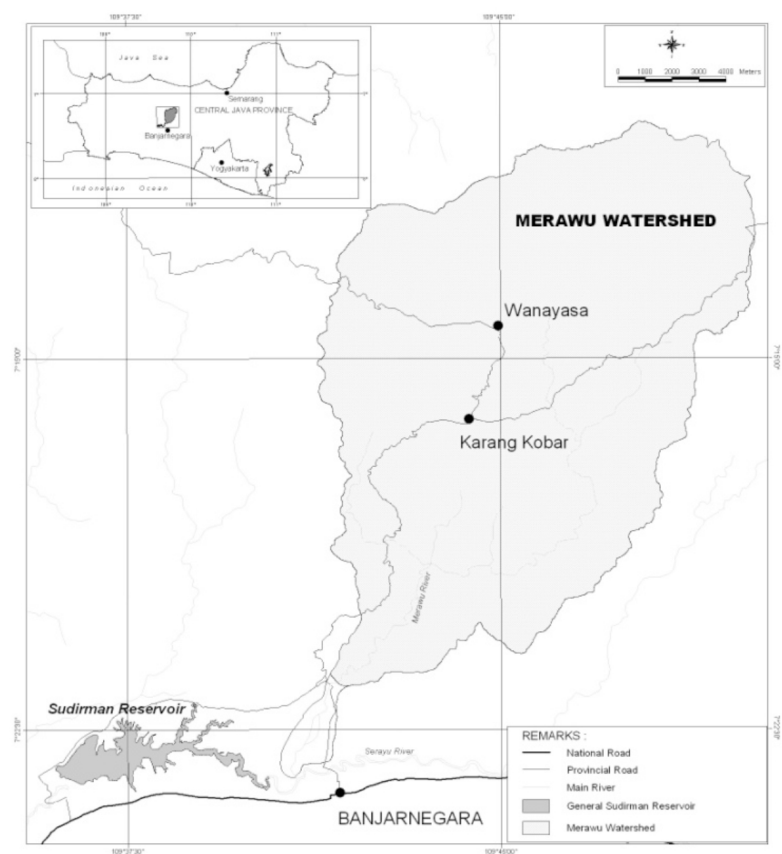

Figure 1 Study area 


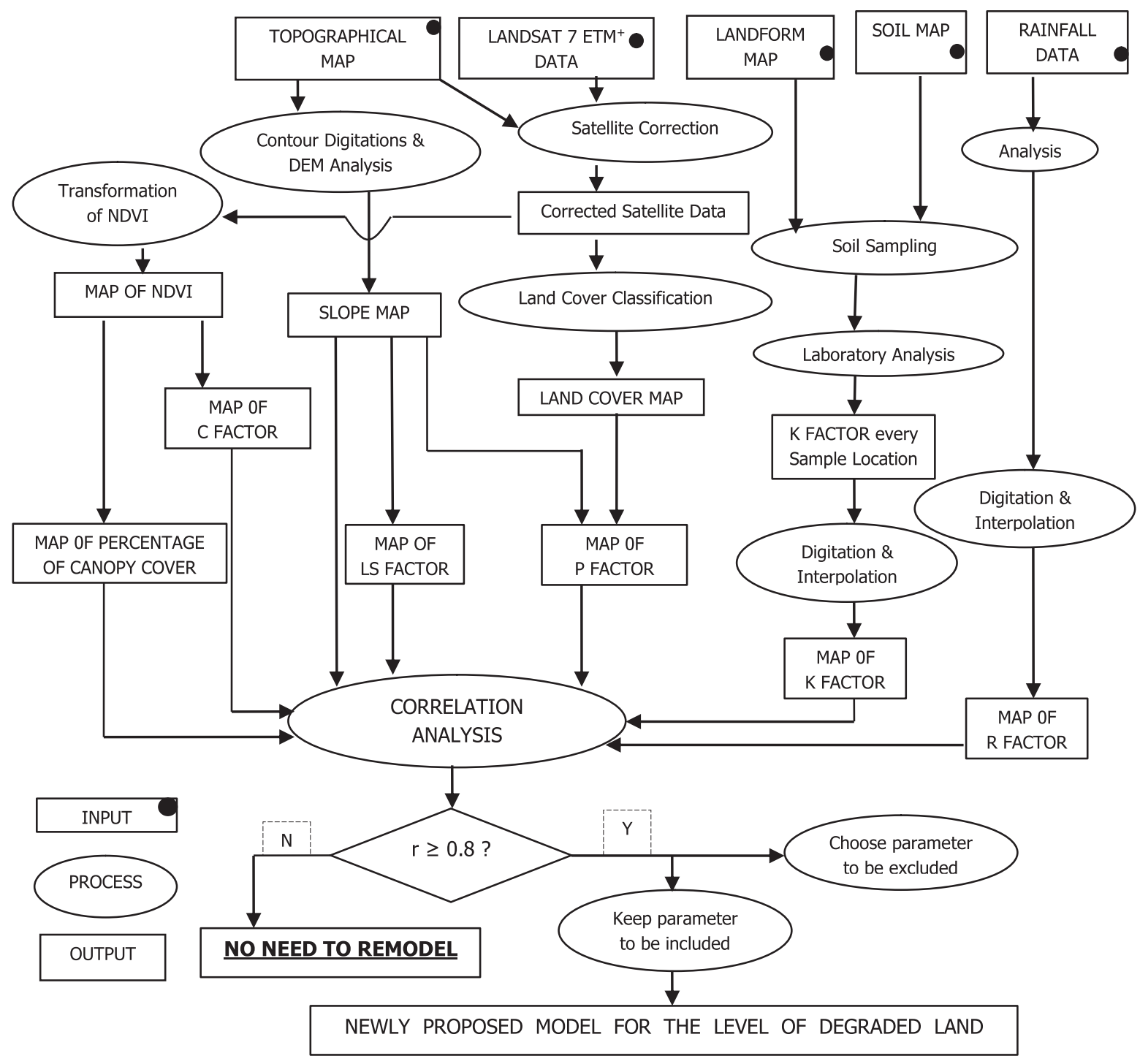

Figure 2 Flow diagram of the study

Management factor were represented by $\mathrm{C}$ and P factors. For further analyses, equation (3) was modified to:

LoDL $=\mathrm{w}_{1}$ Slope $+\mathrm{w}_{2}(\mathrm{R} \times \mathrm{K} \times \mathrm{LS} \times \mathrm{C} \times \mathrm{P})+\mathrm{w}_{3}$ Percentage of Canopy Cover

Equation (4) explicitly showed that the numbers of LoDL parameters were Slope, $\mathrm{R}$ factor, $\mathrm{K}$ factor, LS factor, $\mathrm{C}$ factor, $\mathrm{P}$ factor, and Percentage of Canopy Cover ( 7 parameters).

\section{Creating LoDL Parameters}

LoDL parameters were created by similar methods as the previous studies carried out by the first author (Sulistyo et al. 2009; Sulistyo 2011a; Sulistyo 2011b; Sulistyo et al. 2011; Sulistyo et al. 2013; Sulistyo 2015b; Sulistyo 2016; Sulistyo et al.
2017). The exception was the use of NDVI to create C factor; therefore, C factor was formulated as (Sulistyo et al. 2011):

$\mathrm{C}=0.6-0.77 \times \mathrm{NDVI}$

Percentage of Canopy Cover was formulated as (Sulistyo et al. 2013):

$\%$ CC $=118.33 \times$ NDVI -17.605

The NDVI can be extracted from satellite data to obtain information on land cover according to its density. NDVI was formulated as (Silleos et al. 2006):

$\mathrm{NDVI}=(\mathrm{NIR}-\mathrm{R}) /(\mathrm{NIR}+\mathrm{R})$

where:

NIR $=$ Near Infrared band

$\mathrm{R}=$ Red band 


\section{Correlation Analysis among LoDL Parameters}

In relation to the raster-based degraded land modeling, each parameter contained spatial information or pixel value. Pixel value for each parameter of the LoDL was then viewed as pixel value for each band or channel in remote sensing digital image.

Correlation analysis, as one of multi-band statistics in remote sensing analysis, was applied to determine the closeness of one band toward other bands (Ilwis User's Guide 2002; Lillesand et al. 2004). Individual bands of a multi-spectral image are often highly correlated, implying data redundancy and duplication. Correlation matrix was implemented to evaluate the degree of correlation between individual bands. Correlation matrix (a normalized form of covariance matrix) has values in the range of -1 to 1 , representing a strong negative correlation to a strong positive correlation, respectively. Values close to zero represent weak correlation. Bands showing the least correlation, which implied the largest amount of image variations, were chosen to be included in the multi-band composite, prior to conducting multi-spectral classification analysis. LoDL parameters having the least correlation value were chosen to be included in the model. Correlation value is classified as " $h i g h$ " if the correlation value is $\geq 0.8$ (Gordon et al. 1992).

\section{RESULTS AND DISCUSSION}

Maps of each LoDL parameters in rasterbased data format are presented in Figures 3 to 9, while the correlation matrix of LoDL parameters is presented in Table 1.

Table 1 shows that almost all LoDL parameters has low correlation values i.e. between 0.01 ( $\mathrm{P}$ factor and $\mathrm{K}$ factor) and 0.44 (P factor and Slope). Percentage of Canopy Cover had high negative correlation value with $\mathrm{C}$ factor $(\mathrm{r}=-1.00)$, meaning that an increase in Percentage of Canopy Cover would cause a decrease in $\mathrm{C}$ factor. Slope had high positive correlation value with LS factor ( $\mathrm{r}$ $=0.99)$, meaning that an increase in Slope would cause an increase in LS factor.

Renard et al. (1997) formulated C factor to be calculated from multiplying Prior Land Use (PLU) and Percentage of Canopy Cover assessed for different cover types (CC) and surface cover (SC). This meant that inclusion of the Percentage of Canopy Cover in LoDL formula was redundant.

Slope length and steepness factor (LS factor) consists of two subfactors, i.e. the slope length (L) and the slope gradient $(\mathrm{S})$. Slope length $(\mathrm{L})$ is defined as: "the distance from the point of origin of the surface flow to the point where each slope gradient $(\mathrm{S})$ decreases enough for the beginning of deposition or when the flow comes to concentrate in a defined channel" (Wischmeier \& Smith 1978). This meant that inclusion of Slope in LoDL formula was redundant.

Based on those results and reasons, it was concluded that Percentage of Canopy Cover should not be used simultaneously with $\mathrm{C}$ factor in determining the LoDL and that Slope should not be used simultaneously with LS Factor. Therefore, formula to determine LoDL should only use parameters of USLE model because USLE model has considered all biophysical aspects affecting LoDL. The revised model to calculate LoDL is:

LoDL $\approx$ Erosion $\approx \mathrm{R} \times \mathrm{K} \times \mathrm{LS} \times \mathrm{C} \times \mathrm{P}$

The revised model is in line with the conclusion stated by Abdurachman and Sutono (2002) that the LoDL in Indonesia is mainly caused by erosion due to high amount and

Table 1 Correlation matrix of LoDL parameters

\begin{tabular}{lccccccc}
\hline & $\mathrm{C}$ & $\mathrm{K}$ & $\mathrm{LS}$ & $\mathrm{P}$ & Slope & \% Canopy & $\mathrm{R}$ \\
\hline $\mathrm{C}$ & 1.00 & 0.09 & -0.26 & -0.32 & -0.26 & $\mathbf{- 1 . 0 0}$ & -0.04 \\
$\mathrm{~K}$ & 0.09 & 1.00 & 0.06 & 0.01 & 0.06 & -0.09 & 0.21 \\
LS & -0.26 & 0.06 & 1.00 & 0.39 & $\mathbf{0 . 9 9}$ & 0.26 & 0.01 \\
P & -0.32 & 0.01 & 0.39 & 1.00 & 0.44 & 0.32 & 0.06 \\
Slope & -0.26 & 0.06 & $\mathbf{0 . 9 9}$ & 0.44 & 1.00 & 0.27 & 0.03 \\
\% Canopy & $-\mathbf{1 . 0 0}$ & -0.09 & 0.26 & 0.32 & 0.27 & 1.00 & 0.04 \\
R & -0.04 & 0.21 & 0.01 & 0.06 & 0.03 & 0.04 & 1.00 \\
\hline
\end{tabular}


Proposed model on levels of degraded land at Merawu Watershed, Indonesia - Sulistyo et al.

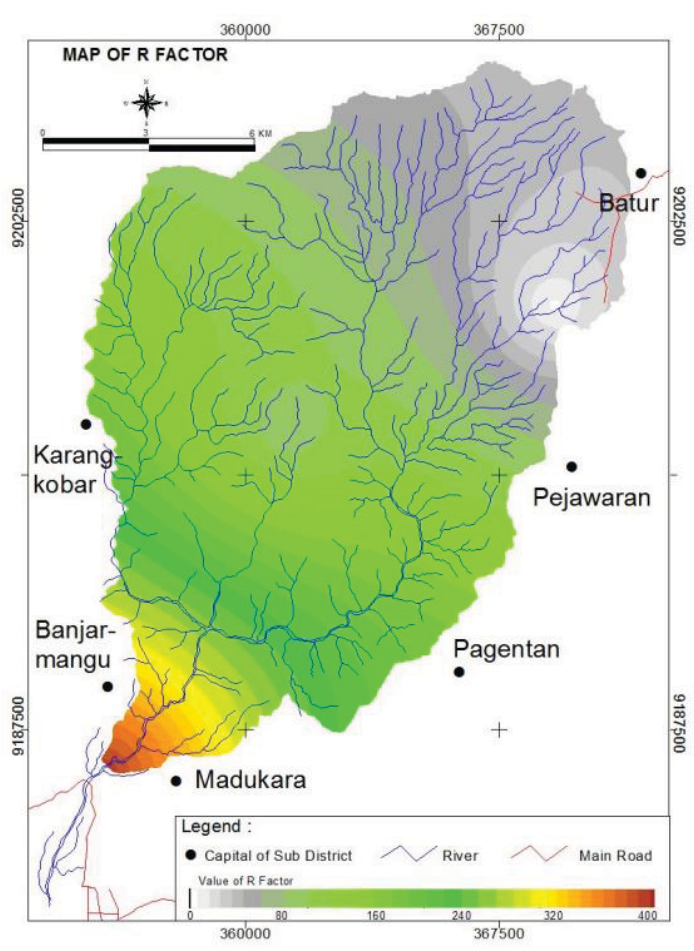

Figure 3 Map of $\mathrm{R}$ factor

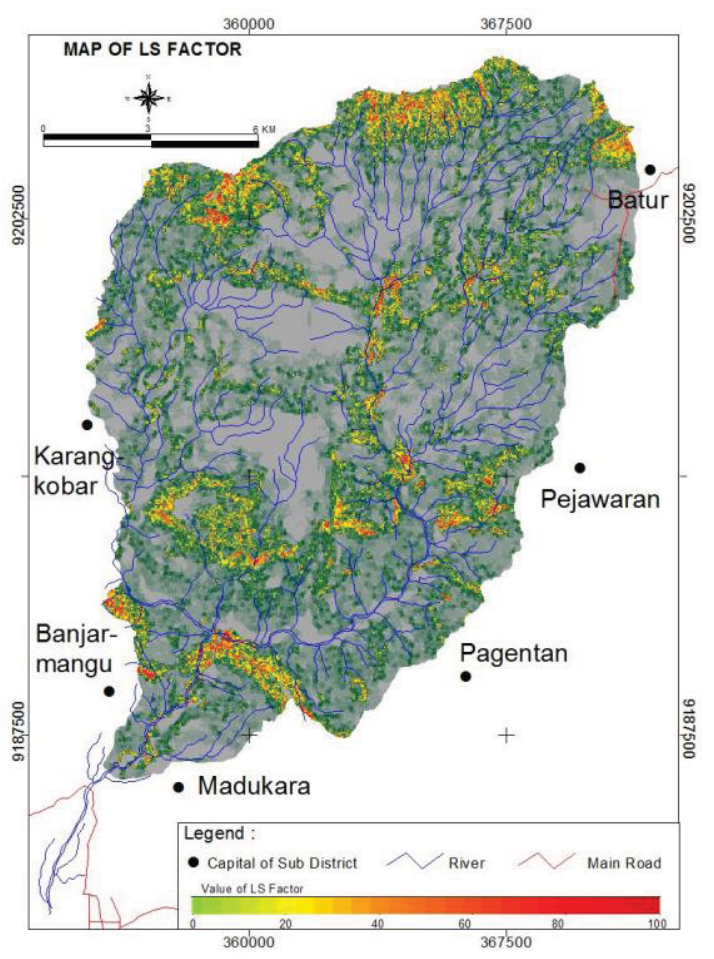

Figure 5 Map of LS factor

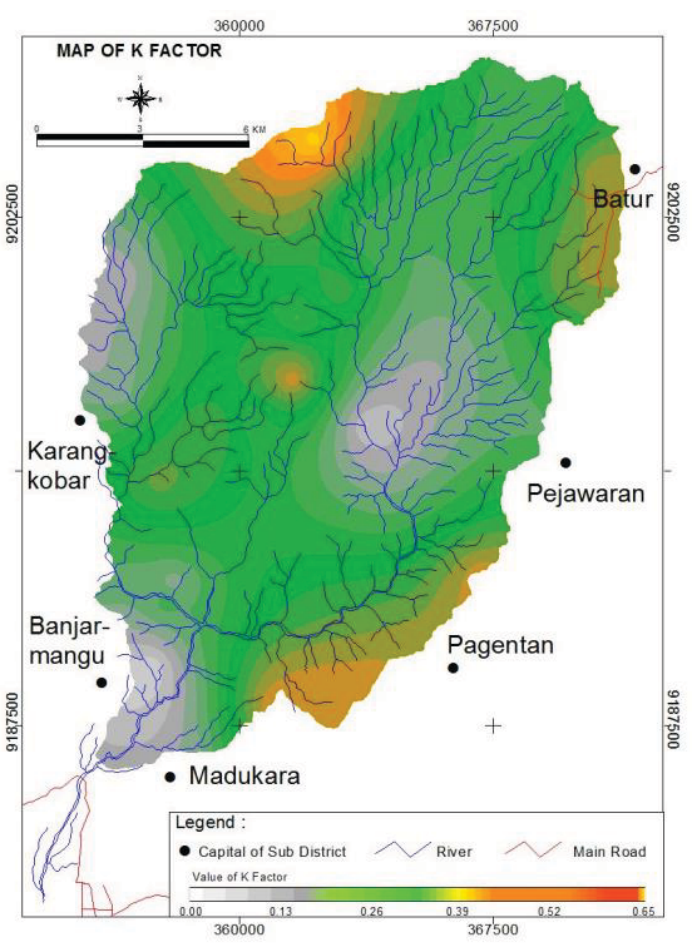

Figure 4 Map of $\mathrm{K}$ factor

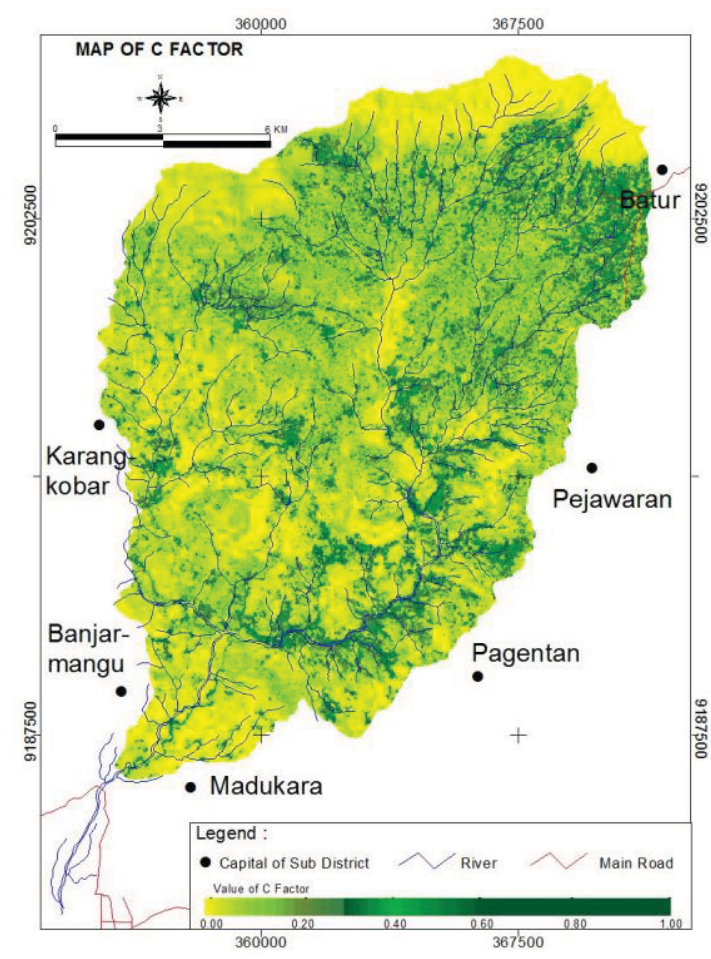

Figure 6 Map of $\mathrm{C}$ factor 


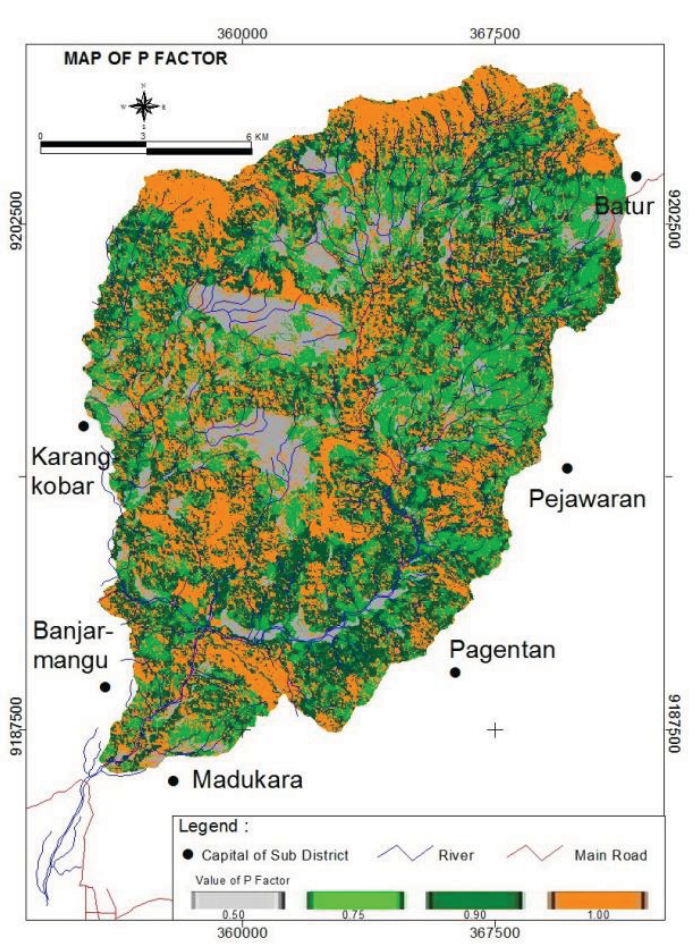

Figure 7 Map of P factor

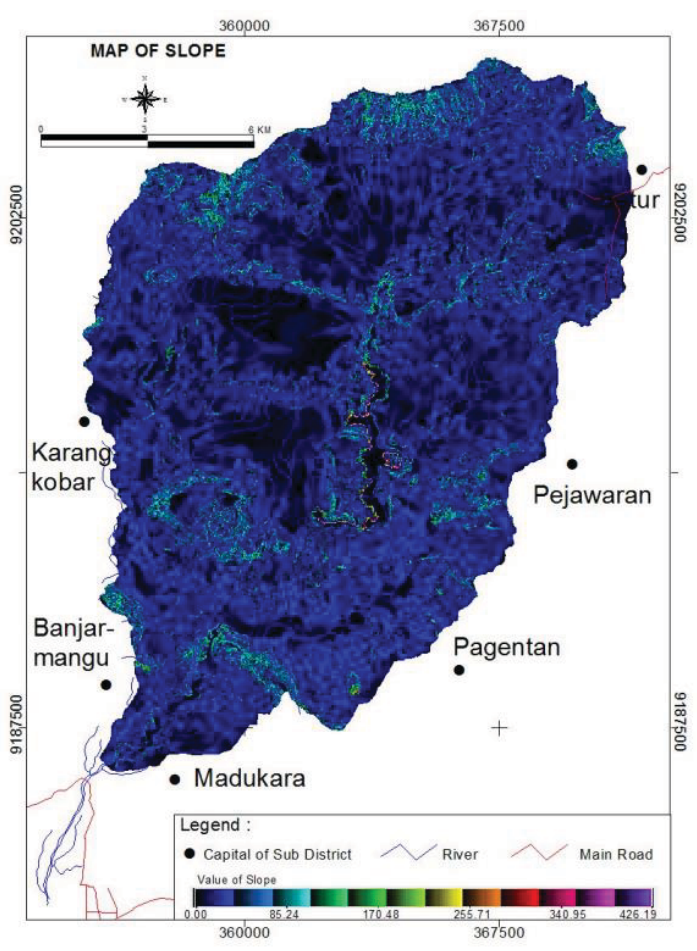

Figure 8 Map of Slope

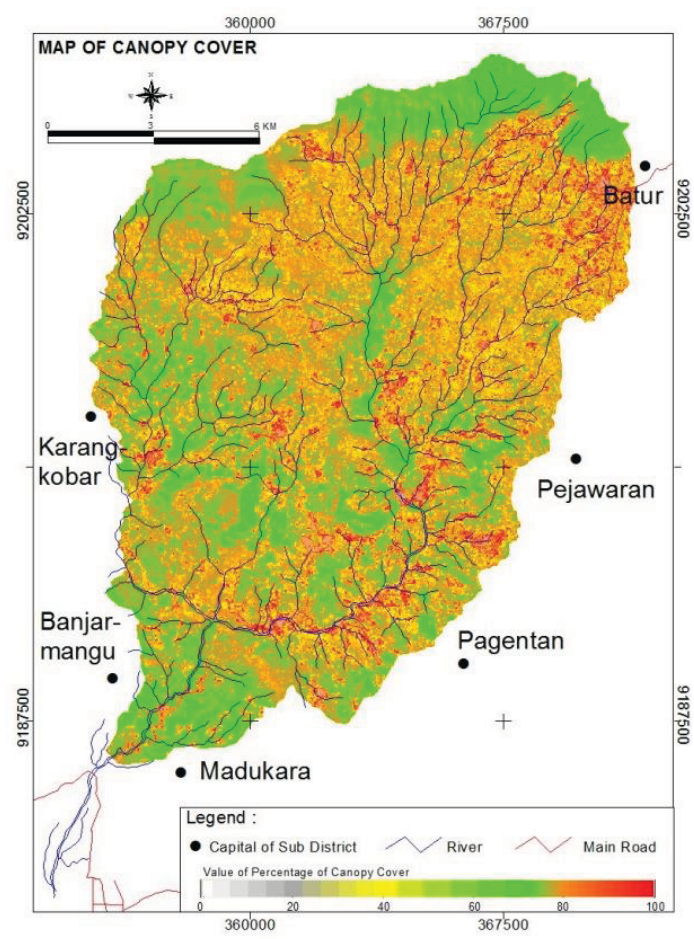

Figure 9 Map of Percentage of Canopy Cover 


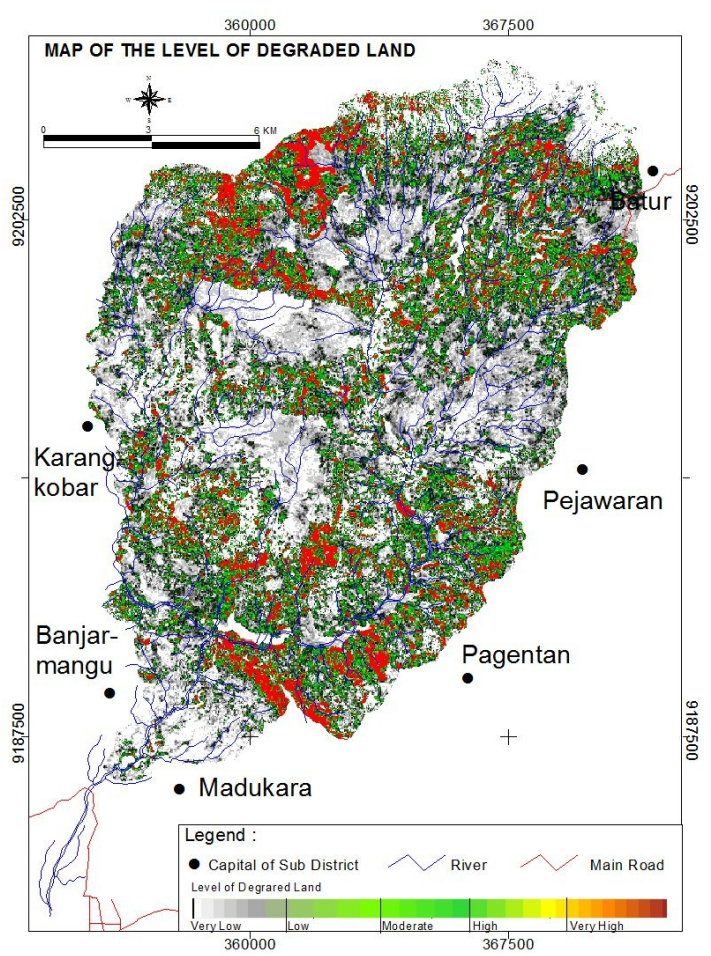

Figure 10 Results of the revised LoDL model

Table 2 The area of each class of the LoDL at Merawu Watershed

\begin{tabular}{lllrr}
\hline No & Level & $\begin{array}{l}\text { Erosion } \\
\text { (mm/year })\end{array}$ & $\begin{array}{c}\text { Area } \\
\text { (ha) }\end{array}$ & $\begin{array}{c}\text { Area } \\
(\%)\end{array}$ \\
\hline 1. & Very low & 0.01 to 1 & 12,470 & 54.9 \\
2. & Low & 1.01 to 2 & 3,421 & 15.1 \\
3. & Moderate & 2.01 to 3 & 1,714 & 7.5 \\
4. & High & 3.01 to 4 & 982 & 4.3 \\
5. & Very high & $>4$ & 1,993 & 8.8 \\
6. & Areas having vegetation index $\leq 0$ & $(-)$ & 2,151 & 9.5 \\
\hline
\end{tabular}

intensity of rainfall. The erosion terminology is used worldwide as an indicator of degraded land occurrence. This model is identical with the Level of Erosion Hazard (in Bahasa: Tingkat Bahaya Erosi or TBE) which is formulated in the Decree No. 041/Kpts/V/1998 of the then Indonesia's Ministry of Forestry. Level of Erosion Hazard was obtained by overlaying the erosion hazard map, derived from the USLE model, with soil depth map.

The average of soil depth at Merawu Watershed was $2.16 \mathrm{~m}$ (Very Deep). Therefore, the revised LoDL model of this study only considered the erosion occurrence. The results of this revised LoDL model were simplified into 5 classes based on Sturges' Rule (Fig. 10; Table 2).

Table 2 shows that 2,151 ha $(9.5 \%)$ of Merawu Watershed were areas having vegetation index $\leq 0$.
Those areas were areas with water. Merawu Watershed area had 15,891 ha $(70 \%)$ of Very Low and Low levels of degraded land. The other 4,689 ha $(20.6 \%)$ had Moderate, High and Very Highlevels of degraded land.

\section{CONCLUSIONS}

Percentage of Canopy Cover should not be used simultaneously with $\mathrm{C}$ factor in determining the LoDL. Slope should not be used simultaneously with LS Factor. The best scenario was to use only erosion parameter derived from the USLE model to determine the LoDL model. The proposed LoDL model:

LoDL (Level of Degraded Land) $\approx$ Erosion $\approx \mathbf{R}$ $\times \mathrm{K} \times \operatorname{LS} \times \mathbf{C} \times \mathbf{P}$. 


\section{ACKNOWLEDGEMENTS}

The authors thank the Indonesian Directorate General of Higher Education for providing grant to conduct this research.

\section{REFERENCES}

Abdurachman A, Sutono. 2002. Soil erosion control technology. Research and Development of Soil and Agro-climate. Bogor (ID): The Agency for Agricultural Research and Development.

Aronoff S. 1989. Geographic Information Systems: a management perspective. Ottawa (CA): WDL Publication.

Arsyad S. 2000. Konservasi tanah dan air. Bogor (ID): IPB Press.

Asdak C. 2007. Hidrologi dan pengelolaan daerah aliran sungai. Yogyakarta (ID): Gadjah Mada University Press.

Bohre P, Chaubey OP. 2014. Restoration of degraded lands through plantation forests. GJSFR 14:18-27.

Chang KT. 2008. Introduction to geographic information systems. New York (US): McGraw-Hill International.

DeMers MN. 2008. Fundamental of geographic information systems. New York (US): John Wiley \& Sons.

Departemen Kehutanan. 1998. Guideline for the arrangement of planning for land rehabilitation in a watershed area. Jakarta (ID).

Food Agricultural Organization [FAO]. 1994. Land degradation in South Asia: its severity, causes and effects upon the people. Rome (IT): World Soil Resources Reports.

Fulazzaky MA, Gany AHA. 2009. Challenges of soil erosion and sludge management for sustainable development in Indonesia. J Environ Manage 90:2387-92.

Fistikoglu O, Harmancioglu NB. 2002. Integration of GIS with USLE in assessment of soil erosion. Water Resour Manag 16:447-67.

Gibbs HK, Salmon JM. 2015. Mapping the world's degraded lands. Appl Geogr 57:12-21.

Gordon ND, McMohan TA, Finlayson BL. 1992. Stream hidrology: an introduction for ecologist. New York (US): John Wiley \& Sons.

Hadmoko DS. 2007. Toward GIS-based integrated landslide hazard assessment: a critical overview. Indones J Geogr 39:55-77.

Hidayat L, Susanto S, Sudira P, Jayadi R. 2014. Penilaian kinerja pengelolaan daerah aliran sungai berbasis model hidrologi elementer kasus: daerah tangkapan air Waduk Mrica. Agritech 34:337-46.

International Institute for Aerospace Survey and Earth Sciences. 2002. Ilwis User's Guide. Enschede (NL): ITC-ILWIS.

Kartodihardjo H. 2008. Management of natural resources and environment. Bengkulu (ID): Universitas Bengkulu.

Kementerian Kehutanan. 2009. Peraturan Direktur Jenderal Rehabilitasi Lahan dan Perhutanan Sosial tentang Pedoman Monitoring dan Evaluasi Daerah Aliran Sungai, Nomor: P.04/V-Set/2009, Tanggal: 5 Maret 2009. Jakarta (ID).

Lillesand TM, Kiefer RW, Chipman J. 2004. Remote sensing and image interpretation. Fifth edition. New York (US): John Wiley \& Sons.

Renard KG, Forster GR, Weesies GA, McCool DK, Yoder DC. 1997. Predicting soil erosion by water: a guide to conservation planning with the Revised Universal Soil Loss Equation (RUSLE). Washington DC (US): US Department of Agriculture.

Silleos NG, Alexandridis TK, Gitas IZ, Perakis K. 2006. Vegetation indices: advances made in biomass estimation and vegetation monitoring in the last 30 years. Geocarto Int 21:21-8.

Sulistyo B, Gunawan T, Hartono, Danoedoro P. 2009. Toward a fully and absolutely raster-based erosion modeling by using RS and GIS. Indones J Geogr 41:149-70.

Sulistyo B, Gunawan T, Hartono, Danoedoro P. 2011. Pemetaan faktor $\mathrm{C}$ yang diturunkan dari berbagai indeks vegetasi data penginderaan jauh sebagai masukan pemodelan erosi di DAS Merawu (C factor mapping derived from various vegetation indices of remotely sensed data as input for erosion modeling at Merawu Watershed). JML 18:68-78.

Sulistyo B. 2011a. Pengaruh erosivitas hujan yang diperoleh dari rumus yang berbeda terhadap pemodelan erosi berbasis raster (Studi kasus di DAS Merawu, Banjarnegara, Jawa Tengah) (The effect of rain erosivity generated from different formulae on a raster-based erosion). Agritech 31:250-9.

Sulistyo B. 2011b. The effect of choosing different contour interval on a fully raster-based erosion modeling (The case in Merawu Watershed, Banjarnegara, Central Java). JTS 16:258-66.

Sulistyo B, Gunawan T, Hartono, Danoedoro P. 2013. Pemodelan persentase tajuk di DAS Merawu yang diturunkan dari berbagai indeks vegetasi data penginderaan jauh (Modeling of percentage of canopy at Merawu catchment area derived from various vegetation indices of remotely sensed data). For Geo 27:23-32.

Sulistyo B. 2015a. Kajian perubahan tingkat kekritisan lahan sebagai akibat proses eliminasi unit lahan: studi kasus di kawasan pertambangan Danau Mas Hitam, 
Provinsi Bengkulu (The study of land degradation level as a result of land unit elimination process: case study in mining region of Danau Mas Hitam, Bengkulu Province). National Seminar on Biodiversity, University Club. Yogyakarta (ID): University of Gadjah Mada. p. 828-33.

Sulistyo B. 2015b. Pemodelan faktor K berbasis raster sebagai masukan pemodelan erosi Di DAS Merawu, Banjarnegara, Provinsi Jawa Tengah (Modeling of raster-based of $\mathrm{K}$ factor as input for erosion modeling at Merawu Catchment Area, Banjarnegara, Central Java Province). Jurnal Manusia dan Lingkungan 22:240-6.

Sulistyo B. 2016. The effect of choosing three different C factor formulae derived from NDVI on a fully raster- based erosion modeling. IOP Conf Ser: Earth Environ Sci 47(1):1-10. doi:10.1088/17551315/47/1/012030.

Sulistyo B, Gunawan T, Hartono, Danoedoro P, Listyaningrum N. 2017. Absolute accuracy of the erosion model of DEM-NDVI and it's modification. IJG 13:23-34.

Tarigan SD. 2012. Methods for delineating degraded land at Citarum Watershed, West Java, Indonesia. J Tropical Soils 17:267-74.

Wischmeier WH, Smith DD. 1978. Predicting rainfall erosion losses: a guide to conservation planning. Washington DC (US): USDA Agriculture Handbook No. 37. 